\title{
Methods of Harmonisation in EU Climate and Energy Directives and their Impact on the Content and Interpretation of National Law
}

\section{Preliminary Issues}

As the climate and energy policy constitutes a constantly expanding domain of legislative activity of the European Union, within that field there have appeared many EU directives (such as ones concerning the promotion of renewable energy sources, carbon capture and storage or, last but not least, emissions trading) that often represent miscellaneous methods of harmonisation. As for environmental law, it is often invoked that mainly two types of harmonisation are applied by the European Union, namely partial harmonisation and minimal harmonisation. Despite its prima facie simplicity, the division may, in certain cases, be not easy to apply in practice. Sometimes it is difficult to make an unambiguous classification as the method of harmonisation of a given directive is concerned. That is true especially for climate and energy directives where a characteristic tension may be perceived. Namely, that sphere at the level of European Union law is, as a rule, regulated by directives, in accordance with the logic of shared competences and subsidiarity principles. On the other hand, as time goes by, the policy of the European Union with regard to the area in question becomes increasingly stringent. The tension affects both the shape of national law implementing the directives and interpretation thereof, rendered by courts as well as public administration bodies. Thus, it is worthwhile to examine that influence and the results thereof. The analysis will first focus on the nature and basic types of harmonisation employed by European Union directives, seeking to answer the question how the manner of harmonisation chosen by the European Union influences national legal orders as well as the character of harmonisation of environmental law of the Member States. Thereafter, a case study will be performed, concerning three di-

${ }^{1}$ Ilona Przybojewska, PhD, Chair of Environmental Law, Faculty of Law and Administration, Jagiellonian University. 
rectives embodying distinct types of harmonisation, namely the emissions trading directive (I would venture saying that it is an example of almost full harmonisation), the directive on renewables and the carbon capture and storage directive (which may be placed at the other end of the spectrum as constituting an example of truly minimal harmonisation).

\section{Nature and Basic Types of Harmonisation by European Union Directives}

\subsection{Harmonisation or Unification? The Role of Proportionality Principle}

Pursuant to Article 296 of the Treaty on the functioning of the European Union ${ }^{2}$, in case of lack of determination of a legal form by a treaty, any recognised instrument may be adopted. The provision seems to leave much leeway for the European legislator as far as the choice among various forms of secondary law of the European Union is concerned. The most important divergence occurs between regulations - with their direct effect and strict provisions - and directives, the latter generally deprived of direct effect and comprising rather general stipulations. However, the discretion here is an illusion as there are some barriers that impede the unfettered exercise of the seeming latitude.

Especially one of them is worth reminding of. The principle of proportionality is one of the most important and the most widely applied principles of law of the European Union ${ }^{3}$. It serves for the purpose of assessment of relations between measures and objectives that are intended to be achieved by the measures in question ${ }^{4}$. As pointed out by the doctrine, crucial requirement lies in the proportionality of legal acts, i.e. adjustment of measures used in the act to the intended goals, enshrined by such a shape of acts that will allow for their effectiveness, whereas encumbering the recipients thereof with the lightest possible burden 5 . The proportionality principle refers, on the one hand, to the choice of a suitable legal form of the regulation and on the other hand to the scope and intensity of necessary regulation ${ }^{6}$. Bearing in mind the aforementioned, it is hard to escape the conclusion that practical implementation of the proportionality principle constitutes a heavy indication in favour of directives against regulations, moreover, to

\footnotetext{
2 Treaty on the Functioning of the European Union (consolidated version), OJ C 83 of 30.03.2010, p. 47-200.

${ }^{3}$ J. Sozański, Prawo Unii Europejskiej. Analiza krytyczna systemu i doktryny, Toruń 2014, p. 163.

${ }^{4}$ D. Miąsik, Zasada proporcjonalności [in:] Zasady ustrojowe Unii Europejskiej, J. Barcz (ed.), Warszawa 2010, p. 140.

${ }^{5}$ J. Sozański, Ogólne zasady prawa (po traktacie lizbońskim) a wartości Unii Europejskiej - studium prawnoporównawcze, Toruń 2012, p. 216.

${ }^{6}$ J. Osiejewicz, Harmonizacja prawa państw członkowskich Unii Europejskiej, Warszawa 2016, p. 74.
} 
the advantage of directives with rather general provisions. This should lead to the selection of harmonisation rather than unification of legal orders of the Member States of the European Union.

\subsection{Harmonisation in Theory and in Practice}

Harmonisation of law consists in ensuring concordance of various legal orders through elimination of divergent elements and overcoming differences so that the functioning of these orders would be in accordance with the aims and interests of engaged entities ${ }^{7}$. The instrument that seems to be tailored for such purpose is the directive which, by virtue of the third paragraph of Article 288 of the TFEU shall be binding, as to the result to be achieved, upon each Member State to which it is addressed, but shall leave to the national authorities the choice of form and methods. That corresponds with a jurisprudential conclusion: Though the Title of the TFEU is silent as to the choice of the regulatory instruments, directives have always been preferred to regulations, and framework directives to detailed directives. What is more, over these last years, subsidiarity signals a shift away from detailed harmonization and towards a more flexible regulatory style characterized by vague objectives leaving ample room for manoeuvre . $^{8}$

Nevertheless, it should be emphasised that directives are very divergent within the scope of their form as some of them regulate only goals but others include very detailed regulation. In case of minimal harmonisation, norms of directives constitute the 'floor', whereas the 'ceiling' is constructed with norms of the Treaties. ${ }^{9}$. In case of partial harmonisation, the division seems rather vague. Full harmonisation is a form that actually dims the difference between harmonisation and unification and, theoretically, should not be allowed in directives. Another division encompasses two categories of harmonisation, namely vertical harmonisation - in which case a directive includes more detailed regulations but has a narrower scope ${ }^{10}$ and horizontal harmonisation - when provisions of a directive are general to a great extent but their nature is cross-sectional (the scope of provisions is wider).

With regard to all forms, there may arise problems with implementation, which in the first case will consist in improper use by the Member States of their discretion with regard to the choice of measures to ensure the effectiveness of directives, whereas in the latter case there appears a temp-

${ }^{7}$ J. Osiejewicz, Harmonizacja prawa państw członkowskich Unii Europejskiej, Warszawa 2016, p. 12.

${ }^{8}$ N. de Sadeleer, Principle of Subsidiarity and the EU Environmental Policy, „Journal of European Environmental and Planning Law" 2012, No. 1, p. 66.

${ }^{9}$ B. Kurcz, Komentarz do art. 288 Traktatu o funkcjonowaniu Unii Europejskiej [in:] Traktat o funkcjonowaniu Unii Europejskiej. Komentarz, t. III, A. Wróbel (ed.), Warszawa 2012, p. 659.

${ }^{10} \mathrm{~J}$. Osiejewicz, Harmonizacja prawa państw członkowskich Unii Europejskiej, Warszawa 2016, p. 62. 
tation of verbatim copying to the national law - which may not ensure its effectiveness due to lack of adjustment to the legal order of a given state ${ }^{11}$. Typical problematic techniques of implementation, representing two most extreme methods, are gold plating and the copy-paste technique. Also, lack of proper or prompt implementation of directives is often a problem.

The aforementioned obstacles seem to be a paradox as actually the form of directives was intended to be a concession for the Member States that did not wish to pass too much of their sovereign spheres of activity to the European Union. The problem is well illustrated by studies performed by J. Maśnicki. With regard to the implementation of climate and energy directives, that author, analysing the punctuality of the implementation of particular elements of the climate and energy package, drew the conclusion that delays within that scope were the rule and the average time between the lapse of a deadline for the transposition on one hand and the entry into force of implementing acts on the other amounted to 29 months ${ }^{12}$. Furthermore, the implementation was achieved, in case of a vast majority of the directives in question, due to the activity of the European Commission ${ }^{13}$, consisting in issuance of justified opinions by virtue of Article 258 of the Treaty on the functioning of the European Union.

As it can be easily seen, in some cases the choice of the directive as a legal form to be used leaves hardly any discretion for the Member States as to the choice of form and methods of achievement of aims imposed by a given directive, whereas it encumbers them with an onerous duty of the performance of implementation works. That problem seems to be especially acute within the framework of European Union environmental law which is often perceived as one of the most infringement-prone spheres of activity, taking into consideration numerous actions brought by the European Commission against various Member States, accusing them of improper, delayed or even non-existent implementation despite the lapse of an established deadline. Troublesome implementation of directives within the policy in the domain of natural environment seems to have also a separate source laying in its specificity, bearing in mind the aforementioned statement that it remains a sphere which is most vulnerable to infringements when compared with other policies of the European Union ${ }^{14}$.

${ }^{11}$ J. Sommer, The Organisational and Legal Instruments Available for Harmonising Polish Environmental Law with EC Environmental Law [in:] Reform in CEE-Countries with Regard to European Enlargement, M. Schmidt et al. (ed.), Berlin-Heidelberg 2004, p. 31.

${ }^{12} \mathrm{~J}$. Maśnicki, Wymuszona implementacja? Postępowania $z$ tytułu uchybienia zobowiązaniom traktatowym $w$ sprawie dyrektyw realizujacych politykę energetyczno-klimatyczna [in:] Inteligentna i zrównoważona gospodarka sprzyjająca włączeniu społecznemu - wyzwania dla systemów prawnych Unii Europejskiej i państw członkowskich, S. Dudzik, B. Iwańska, N. Półtorak (eds.), Warszawa 2017, p. 281.

${ }^{13}$ Ibidem, p. 285.

${ }^{14}$ H.T. Anker, K. de Graaf, R. Purdy, L. Squintani, Coping with EU Environmental Legislation - Transposition Principles and Practices, "Journal of Environmental Law” 2015, Vol. 27, p. 19. 
According to the European Court of Justice, the scope of discretion with regard to implementation is determined by the aim, wording and structure of the directive ${ }^{15}$. In the judgment of the European Court of Justice issued in $R T I^{16}$, the Court suggested employing historical interpretation in case of determination of borders of the 'occupied field' as well as borders of margin of implementation discretion of the Member States. Although it is theoretically possible for an objective 1 of a directive to be already attained in the national legal order without the necessity of taking implementation measures after the adoption of that directive at the level of the European Union, in practice, as J. Maśnicki noticed, the European Court of Justice has never agreed with any Member State claiming that the effectiveness of a given directive is guaranteed by the already binding provisions of domestic law ${ }^{17}$.

The impact of the choice made by the European legislator with regard to the manner of harmonisation employed by a given directive is significant. It should be noted that if the harmonisation is not deep, the Member States create legal solutions implementing the directive depending on their attitude to a given instrument proposed by the European Union. Therefore, the legal solutions introduced by them may be based on their particular interests or convictions. In case of partial or full harmonisation, although it is not easy for the Member States to imprint their attitudes in the process of implementation, they sometimes do use creative remedies that actually circumvent the purpose of the directive. As far as the range of regulations is concerned, prima facie it would seem that the more stringent harmonisation, the bigger portion of legal provisions will be introduced by the Member States. However, that is not completely true because in case of a significant number of directives that are general in their wording a great legislative effort is required from the Member States to create specific regulations that would ensure the achievement of the goals stipulated by the directive. It is not an easy task as such goals are sometimes - and within environmental, in particular the climate and energy policy of the European Union, as a rule - expressed as delayed in time. Therefore, the nature of harmonisation provided by EU environmental law should be analysed.

${ }^{15}$ Judgment of the European Court of Justice of 25 April 2002 in case C-183/00, Maria Victoria González Sánchez against Medicina Asturiana SA.

${ }^{16}$ Judgement of the European Court of Justice of 12 December 1996 in joined cases C-320/94, C-328/94, C-329/94, C-337/94, C-338/94 and C-339/94, Reti Televisive Italiane SpA (RTI) (C-320/94), Radio Torre (C-328/94), Rete A Srl (C-329/94), Vallau Italiana Promomarket Srl (C-337/94), Radio Italia Solo Musica Srl i in. (C-338/94) i GETE Srl (C-339/94) v. Ministero delle Poste e Telecommunicazioni.

${ }^{17}$ J. Maśnicki, Metody transpozycji dyrektyw, „Europejski Przegląd Sądowy” 2017, No. 8, p. 4. 


\section{Nature of Harmonisation of the Environmental Law of the Member States}

In the domain of the environment, European Union law is dominated by directives, thus in the doctrine there appeared statements characterised by minimal harmonisation through adoption of directives with objectives determined in a flexible manner ${ }^{18}$. However, the question is not so simple and again, it seems indispensable to refer to the specificity of environmental law and policy.

As regards the natural environment, policy boundaries are fluid ${ }^{19}$ and its shape depends to a great extent on the resolution of interdisciplinary issues. In the doctrine, it is emphasised that a replacement of directives with regulations may not be a proper rectification of the problem because many regulations are actually not of self-executing nature, therefore there may occur the problem of supervision over their appropriate application by the Member States ${ }^{20}$. Moreover, the environmental policy of the European Union constitutes one of the most fast-moving spheres of activity of that organisation ${ }^{21}$; however, there is a considerable gap between 'law in the books' and 'law in practice', which renders the effective implementation of directives within that policy a significant challenge ${ }^{22}$. That corresponds with a conclusion made in the doctrine, stating that everybody within the Community agrees on the EC Treaty's objectives of sustainable development, of a high level of protection, of the application of the precautionary, prevention, and the polluter pays principles. The devil is always in the detail: how to apply these objectives and principles, in the urban environment, to water contamination, soil erosion, the disappearance of species of fauna and flora or climate change (...) The more the Community resorts to general notions, to quality standards, to plans and reports as instruments for environmental improvement, the more difficult will be the coherent and consistent application of environmental provision ${ }^{23}$. In case of the application of minimal harmonisation as a preferred form, a significant risk has been noticed; namely, there appeared the question as to whether the whole concept of minimum harmonization, combined with a no gold plating policy, will lead to a socalled 'race to the bottom'. This does appear to be a consequence, and in many

${ }^{18}$ P. Wennerås, The Enforcement of EC Environmental Law, Oxford 2007, p. 72.

${ }^{19}$ A. Macintosh, D. Wilkinson, Complexity Theory and the Constraints on Environmental Policymaking, „Journal of Environmental Law” 2016, Vol. 28, p. 92.

${ }^{20}$ H.T. Anker, K. de Graaf, R. Purdy, L. Squintani, Coping with EU Environmental Legislation..., p. 20.

${ }^{21}$ S. Kingston, Surveying the State of EU Environmental Law: Much Bark with Little Bite?, „International and Comparative Law Quarterly” 2013, Vol. 4, p. 965.

${ }^{22}$ Ibidem, p. 982.

${ }^{23}$ L. Krämer, Differentiation in EU Environmental Policy, „European Energy and Environmental Law Review" 2000, No. 5, p. 140. 
Member States we have found examples of downgrading national standards to the lower European ones ${ }^{24}$.

Ingmar von Homeyer has observed a differentiation in governance regimes in the EU environmental policy, changing and overlapping over time. According to him, at least four regimes may be noticed, namely, the 'environment regime' (from 1972), the 'internal market regime' (from 1982), the 'integration regime' (from 1992), and the 'sustainable development regime' (from 1998). The divergences between them consist, inter alia, in the features of legislation at the level of the European Union, which conditions the manner of ensuring their effectiveness by Member States. From the point of view of that author: In terms of instruments, the environment regime typically relies on legally binding, top-down regulation. The regime's focus on acute health and environmental problems and its reliance on expertise in the decision-making process partly accounts for this. More specifically, the real or perceived acuteness of problems and the science-based substantive contents of legislation require quick and full implementation. Legally binding, top-down regulation allows for exact instructions to implementing bodies, is associated with a high level of obligation, and enables the use of mostly pre-established administrative structures ${ }^{25}$. In turn, Harmonization measures feature as the type of instrument that is most closely associated with the internal market regime. As with the environment regime, these measures frequently take the form of legally binding, top-down regulation. However, the administrative and budgetary burden is likely to be lower than in the case of the environment regime because ensuring compliance largely falls to private actors ${ }^{26}$. From the point of view of Ingmar von Homeyer, the integration regime allowed for a shift away from the regulatory harmonization approach of the internal market regime towards the integration regime's focus on economic efficiency and environmental effectiveness - both of which frequently require a certain degree of flexibility and decentralization at the cost of harmonization ${ }^{27}$. (...) The integration regime's environmental measures are characterized by vague objectives which leave room for flexibility and an integrated approach (...). Framework Directives are the most characteristic regulatory instruments associated with the integration regime. Reflecting their integrative ambition, these directives tend to have a relatively broad scope. They can cover various environmental media, quality and emission limits, or a range of pollutants that were previously regulated separately. The framework directives establish binding procedures, for example regarding planning, permitting,

${ }^{24}$ J.H. Jans, L. Squintani, A. Aragão, R. Macrory, B.W. Wegener, 'Gold plating' of European Environmental Measures?, "Journal of European Environmental and Planning Law" 2009, No. 4, p. 427.

${ }^{25}$ I. von Homeyer, The Evolution of EU Environmental Governance [in:] Environmental Protection. European Law and Governance, J. Scott (ed.), Oxford 2009, p. 10.

${ }^{26}$ Ibidem, p. 13.

${ }^{27}$ Ibidem, p. 15. 
measurements and reporting, or regulate the relationship among related and 'daughter' directives which, in turn, contain the relevant substantive requirements. This procedural approach is complemented by 'horizontal' measures which help to render the procedures effective, for example by enhancing the availability of information and by bestowing rights on stakeholders ${ }^{28}$. As the aforementioned author points out, the last of the differentiated regimes, the sustainable development regime, is primarily focused on persistent environmental problems that are frequently linked to structural properties of the economic sectors causing the problems and are characterized by complex causal chains and delayed effects resulting in low visibility and uncertain$t y^{29}$ (...). An important feature of the sustainable development regime is that when it comes to decision-making, implementation rather than formulation of the original EU measures is critical. This is because the original measures tend to be highly underdetermined ${ }^{30}$.

My opinion is that the environmental policy of the European Union is currently focused on climate and that it has changed a lot with regard to the governance model. Namely, there are applied long-term goals with an increased use of economic instruments of environmental protection. The target remains crucial, but at least two models of getting there are applied. It resembles a test employed by the European Union legislator - the test that demonstrates interesting results.

\section{Case Study: Methods of Harmonisation Used in Climate and Energy Directives}

Within the framework of leadership concerning international efforts in combat with climate changes, the European Union has attempted to demonstrate that decarbonisation is compatible with other important aims, such as energy security, economic growth or competitiveness ${ }^{31}$. However, many scholars have perceived fundamental lack of cohesion even between miscellaneous instruments of the climate and energy policy. As J.B. Skjærseth pointed out, climate and energy policy instruments intended to be mutually reinforcing have developed into a relationship characterized by conflict, caused mainly by a combination of the economic crisis and institutional design: the unhappy marriage between the EU ETS and policies to promote renewables, energy efficiency and access to external CDM credits. The resultant low carbon price undermines funding for CCS, renewables and

${ }^{28}$ Ibidem, p. 17-18.

${ }^{29}$ Ibidem, p. 19.

${ }^{30}$ Ibidem, p. 20.

${ }^{31}$ C.F. Parker, C. Karlsson, The European Union as a Global Climate Leader: Confronting Aspiration with Evidence, „International Environmental Agreements: Politics, Law and Economics" 2017, No. 4, p. 450. 
other low-carbon solutions ${ }^{32}$. Moreover, not all climate policy integration is necessarily beneficial for the environment and therefore contributes to sustainable development ${ }^{33}$, although provisions connected with climate change are often perceived in the context of the problem of unsustainable use of non-renewable energy sources ${ }^{34}$.

All the aforementioned results in the inevitable diversity of instruments related to the climate and energy policy. Not only are they different with regard to their nature but also - which is important in the context of this article - as to their shaping embodied by the choice made as to the method of harmonisation.

\subsection{Emissions Trading Directive - Method of Harmonisation Used and its Influence on Domestic Law}

Directive 2003/8/WE (as amended) sets forth the European Union Emissions Trading System which constitutes an example of the utilisation of a market-based instrument to enshrine values of environmental law. As L. Karski wrote, in case of market-based instruments, such as quotas of emissions, both the cost of use of environmental resources and remuneration for the desired activity will be shaped by supply and demand, which results in an increased level of economic risk, in comparison to financial and legal measures, but at the same time that elevates the chance of a lower price of quotas ${ }^{35}$. Nevertheless, despite an increasing number of examples in which market-based instruments are being applied, direct regulation still dominates the environmental playing field. Planning, quality standards, permits and general permissions and EIA [environmental impact assessment] add to a careful and increasingly more sophisticated and integrated environmental decision making process ${ }^{36}$.

Although market-based environmental instruments are often invoked as a solution that allows for a great degree of flexibility when compared with traditional regulatory instruments, strangely enough Directive 2003/87/ EC establishing a scheme for greenhouse gas emission allowance trading

${ }^{32}$ J.B. Skjærseth, Linking EU Climate and Energy Policies: Policy-Making, Implementation and Reform, „International Environmental Agreements: Politics, Law and Economics" 2016, Vol. 16, p. 521.

${ }^{33}$ K. Rietig, Sustainable Climate Policy Integration in the European Union, „Environmental Policy and Governance" 2013, Vol. 23, p. 298.

${ }^{34}$ A. Fischer, V. Peters, M. Neebe, J. Vávra, A. Kriel, M. Lapka, B. Megyesi, Climate Change? No, Wise Resource Use is the Issue: Social Representations of Energy, Climate Change and the Future, „Environmental Policy and Governance” 2012, Vol. 22, p. 161.

${ }^{35}$ L. Karski, Wdrażanie instrumentów rynkowych prawa ochrony środowiska [in:] Dekada harmonizacji w prawie ochrony środowiska, M. Rudnicki, A. Haładyj, K. Sobieraj (ed.), Lublin 2011, p. 419.

${ }^{36}$ M.A. Heldeweg, R.J.G.H. Seerden, K.R. Deketelaere, Public Environmental Law in Europe: a Comparative Search for a Ius Commune, „European Environmental Law Review" 2004, No. 3, p. 85. 
within the Community and amending Council Directive $96 / 61 /$ EC $^{37}$ is very detailed as to its content. Article 1 of that directive sets forth the general intent, namely the directive is to establish a scheme for greenhouse gas emission allowance trading within the Community (...) in order to promote reductions of greenhouse gas emissions in a cost-effective and economically efficient manner. The directive is an example of vertical and almost full harmonisation with its specific provisions referring to the indication of general reduction aims to be fulfilled by individual Member States up to a point in the future (the same solution that earned the Kyoto Protocol the nickname 'Kyoto-communism ${ }^{38}$ ), European Union-wide quantity of allowances (which is to decrease gradually by a linear factor of 1,74\%) and auctioning of allowances with strictly determined exceptions (derogations). The picture is supplemented by quite a high number of authorisations that may be found within the directive which gives the European Commission the power to issue many executory regulations. I would even say that the emissions trading directive in practice contravenes the spirit of Article 288 of TFEU and is very specific apart from the technical issues. However, such issues are hard to be resolved so implementation problems arise. Both Polish acts pertaining to the emissions trading system, namely the Act on the system of management of emissions of greenhouse gases and other substances ${ }^{39}$ and the Act on the system of trading of greenhouse gases emissions quotas ${ }^{40}$ bring little novelty with regard to legislative substance when compared to the aforementioned directive, apart from technical issues and institutional framework (partially due to the principle of procedural autonomy belonging to the Member States). However, the strict and detailed regulations imposed by the present version of the directive have not up to now resulted in success with regard to the reduction of emissions of greenhouse gases. That may seem a paradox when we analyse other directives from the energy and climate package.

\subsection{Directive Concerning the Promotion of Renewable Energy Sources - Method of Harmonisation Used and its Influence on Domestic Law}

Minimal harmonisation generally employed by the directive concerning the promotion of renewable energy sources ${ }^{41}$ allows for experiments by

${ }^{37}$ Directive 2003/87/EC of the European Parliament and of the Council of 13 October 2003 establishing a scheme for greenhouse gas emission allowance trading within the Community and amending Council Directive 96/61/EC, OJ L 275 of 25.10.2003, p. 32-46, as amended.

${ }^{38}$ M. Stelmachowski, Handel pozwoleniami na emisję ditlenku wegla jako instrument strategii zrównoważonego rozwoju, Łódź 2006, p. 53-58.

${ }^{39}$ Act of 17 July 2009 on the system of management of emissions of greenhouse gases and other substances, uniform text OJ 2017, item 286, as amended.

${ }^{40}$ Act of 12 June 2015 on the system of trading of greenhouse gases emissions quotas, uniform text OJ 2017, item 568, as amended.

${ }^{41}$ Directive 2009/28/WE of the European Parliament and of the Council of 23 April 2009 on the promotion of the use of energy from renewable sources and amending and 
the domestic legislator, switching from one system of support to another. According to is Article 1, it is intended to establish a common framework for the promotion of energy from renewable sources. It sets mandatory national targets for the overall share of energy from renewable sources in gross final consumption of energy and for the share of energy from renewable sources in transport. It lays down rules relating to statistical transfers between Member States, joint projects between Member States and with third countries, guarantees of origin, administrative procedures, information and training, and access to the electricity grid for energy from renewable sources. It establishes sustainability criteria for biofuels and bioliquids. To tell the truth, little more than the cap is determined apart from more details as regards biofuels and bioliquids, leaving much leeway for the Member States to choose their own path in order to achieve the imposed thresholds. The path to be chosen consists in a 'support scheme' which, by virtue of Article $2(\mathrm{k})$ of the directive, is defined very broadly as any instrument, scheme or mechanism applied by a Member State or a group of Member States, that promotes the use of energy from renewable sources by reducing the cost of that energy, increasing the price at which it can be sold, or increasing, by means of a renewable energy obligation or otherwise, the volume of such energy purchased. This includes, but is not restricted to, investment aid, tax exemptions or reductions, tax refunds, renewable energy obligation support schemes including those using green certificates, and direct price support schemes including feed-in tariffs and premium payments. The only mandatory measures to be implemented are guarantees of origin of electricity, heating and cooling produced from renewable energy sources that are issued for the purposes of proving to final customers the share or quantity of energy from renewable sources in an energy supplier's energy mix (Article 15(1)), as well as priority access or guaranteed access to the grid-system of electricity produced from renewable energy sources (Article 16(2)(b)). The directive seems to oscillate between minimal and partial harmonisation which allows for quite a big amount of novelty to be introduced at the level of the national legal order. Moreover, it also leaves space for changing from one system of support to another, as in case of Poland, which turned to the systems of auctions from the model of green certificates as of July 2016. The Act on renewable energy sources ${ }^{42}$ provides for significant support for the technology of combustion of coal with biomass (precisely speaking, that is accomplished by means of a delegated regulation ${ }^{43}$ by setting a high referential price). In that case, an

subsequently repealing Directives 2001/77/EC and 2003/30/EC, OJ L 140, 05.06.2009, p. 16-62, as amended.

${ }^{42}$ Act of 20 February 2015 on renewable energy sources, OJ 2015, item 478, as amended.

${ }^{43}$ Currently, it is the Energy Minister regulation of 16 March 2017 on the reference price of electrical power from renewable Energy sources in 2017 and periods binding for the generators winning auctions in 2017, OJ of 2017, item 634. 
attempt may be noticed to adjust the provisions of the directive to the aims of the domestic energy policy. Surprisingly, the more flexible attitude of the directive (especially when compared to the directive pertaining to the EU greenhouse gases emissions trading scheme) entailed better effectiveness when it comes to the achievement of goals set by the given directive. However, such effect may not arise in some other cases of minimal harmonisation - as it can be seen in the analysis of the carbon capture and storage directive below ${ }^{44}$.

\subsection{Carbon Capture and Storage (Ccs) Directive - Method of Harmonisation Used and its Influence on Domestic Law}

By virtue of Article 1 of the directive on the geological storage of carbon dioxide, the directive is to establish a legal framework for the environmentally safe geological storage of carbon dioxide $\left(\mathrm{CO}_{2}\right)$ to contribute to the fight against climate change. The second paragraph of Article 1 provides a clarification by stating that the purpose of environmentally safe geological storage of $\mathrm{CO}_{2}$ is permanent containment of $\mathrm{CO}_{2}$ in such a way as to prevent and, where this is not possible, eliminate as far as possible negative effects and any risk to the environment and human health. The method of harmonisation used by that directive may be assessed as minimal since the directive does not even introduce a necessity of implementation of carbon capture and storage technology by the Member States, as according to Article 4(1) Member States shall retain the right to determine the areas from which storage sites may be selected pursuant to the requirements of this Directive. This includes the right of Member States not to allow for any storage in parts or in the whole of their territory. Nevertheless, if given Member States choose to introduce geological capture and storing technology, they shall take into account the necessity to create abundant regulation that would set forth heavy regulatory burdens upon entities wishing to deal with the activity related to that technology, due to the precautionary principle. For instance, by virtue of Article 8 of the directive, the competent authority shall issue a storage permit only if the following conditions are met: 1. the competent authority, on the basis of the application submitted pursuant to Article 7 and of any other relevant information, is satisfied that: (a) all relevant requirements of this Directive and of other relevant Community legislation are met; (b) the operator is financially sound and technically competent and reliable to operate and control the site and that professional and technical development and training of the operator and all staff are provided; (c) in the case of more

${ }^{44}$ Directive 2009/31/EC of the European Parliament and of the Council of 23 April 2009 on the geological storage of carbon dioxide and amending Council Directive 85/337/EEC, European Parliament and Council Directives 2000/60/EC, 2001/80/EC, 2004/35/EC, 2006/12/EC, 2008/1/EC and Regulation (EC) No 1013/2006, OJ L 140 of 5.06.2009, p. 114-135, as amended. 
than one storage site in the same hydraulic unit, the potential pressure interactions are such that both sites can simultaneously meet the requirements of this Directive. An operator of a geological storage site may be released from its extensive duties only after the transfer of responsibility which may be made after the closure of the site only if the following conditions are met: (a) all available evidence indicates that the stored $\mathrm{CO}_{2}$ will be completely and permanently contained; (b) a minimum period, to be determined by the competent authority has elapsed. This minimum period shall be no shorter than 20 years, unless the competent authority is convinced that the criterion referred to in point (a) is complied with before the end of that period; (c) the financial obligations referred to in Article 20 have been fulfilled; (d) the site has been sealed and the injection facilities have been removed (Article 18 of the directive).

Only CCS for demonstration purposes is allowed in the territory of Poland, and even that form of activity is encumbered with significant limitations. First and foremost, the area in which carbon capture and storage is allowed makes taking advantage of such possibility technologically difficult and more expensive than in the case of 'standard' CCS. Under the Regulation, on areas where location of sites of geological carbon dioxide storage is allowed ${ }^{45}$, the only available place in this respect is a Cambrian reservoir within the exclusive economic zone of the Republic of Poland, within the scope of exploited geological layers of hydrocarbons jointly with the surroundings. It means that only offshore CCS for demonstration purposes is allowed. Moreover, the possibility of starting CCS activity even offshore is made conditional upon lack of hazards posed to public security, health and human life as well as the environment (Article 127a(1) of the Geological and Mining Act). If any entity is not sufficiently discouraged by that circumstance, it has to accept numerous and onerous duties the Polish Geological and Mining Act ${ }^{46}$ imposes thereupon, directed by EU regulations ${ }^{47}$.

In practice, the technology of carbon capture and storage is not extensively exploited in the European Union in order to limit emissions of greenhouse gases. It may be the effect of lack of incentives that would act to the advantage of that technology while the prices of emission quotas within the European Emissions Trading Systems amount to approximately a few euro

${ }^{45}$ Regulation of the Minister of the Environment of 3 September 2014 on areas in which the location of geological carbon dioxide storage sites is allowed, OJ 2014, item 1272 .

${ }^{46}$ The Geological and Mining Act of 9 June 2011, uniform text OJ 2016, item 1131, as amended. The CCS directive was implemented to the Polish legal order by the Act of 27 September 2013 on amendment of the Geological and Mining Act and some other Acts, OJ 2013, item 1238.

${ }^{47}$ More about carbon capture and storage in Poland: I. Przybojewska, Legal possibilities of carbon capture and storage in Poland, „Law and Administration in Post-Soviet Europe”, Vol. V, G. Górski, A. Garczewska, W. Sławiński, J. Górska-Szymczak (eds.), Toruń 2018 (publication pending). 
per tonne of carbon dioxide. However, in this case there also seems to exist a 'race to the bottom', entailed by minimal harmonisation with the wording of the provisions of the directive that successfully discourage both private entities and Member States from taking any action related to CCS, mainly due to significant costs and risks.

\section{Conclusions}

Implementation problems in the case of the climate and energy policy seem to be common, irrespective of which method of harmonisation is chosen. That is also reflected at the level of national legal order and the interpretation thereof. Nevertheless, there are a few general conclusions that can be drawn from the considerations above. Namely, the purpose should be to strike a balance between too minimal and too extensive a level of harmonisation. As far as the directives from the climate and energy package are concerned, the most effective instrument up to now has turned out to be the directive on renewables. Comprising a few cornerstones the strict implementation of which is mandatory, that directive in general allows the Member States to act in their discretion. That entails the possibility of adjusting EU legislation to the specificity of national circumstances and that actually cannot be said for the two other aforementioned directives, adopted at the same time, which have failed to prove their effectiveness. Even if the carbon capture and storage directive represents an example of minimal harmonisation, in practice it does not leave much freedom for the Members States - the choice consists mainly in the choice between the absence of CCS or its presence, whereas the latter entails the necessity to impose heavy administrative burdens. The emission trading scheme, on the other hand, forces the Member States to create a complex framework, to a great extent predetermined by the wording of the directive. That confirms the ancient rule about the ideal nature of a golden mean... and also, the difficulty of finding it.

\section{Literature}

Anker H.T., de Graaf K., Purdy r., Squintani L., Coping with EU Environmental Legislation - Transposition Principles and Practices, „Journal of Environmental Law" 2015, Vol. 27.

Banet C., The Use of Market-Based Instruments in the Transition from a Carbon-Based Economy [in:] Beyond The Carbon Economy: Energy Law in Transition, D.N. Zilman, C. Redgwell, Y.O. Omorogbe, L.K. Barrrera-Hernández (eds.), Oxford 2008.

Fischer A., Peters V., Neebe M., Vávra J., Kriel A., Lapka M., Megyesi B., Climate Change? No, Wise Resource Use is the Issue: Social Representations of Energy, Climate Change and the Future, „Environmental Policy and Governance” 2012, Vol. 22. 
Heldeweg M.A., Seerden R.J.G.H., Deketelaere K.R., Public Environmental Law in Europe: a Comparative Search for a Ius Commune, „European Environmental Law Review" 2004, No. 3.

von Homeyer I., The Evolution of EU Environmental Governance [in:] Environmental Protection. European Law and Governance, J. Scott (ed.), Oxford 2009.

Jans J.H., Squintani L., Aragão A., Macrory r., Wegener B.W., 'Gold plating' of European Environmental Measures?, "Journal of European Environmental and Planning Law" 2009, No. 4.

Karski L., Wdrażanie instrumentów rynkowych prawa ochrony środowiska [in:] Dekada harmonizacji w prawie ochrony środowiska, M. Rudnicki, A. Haładyj, K. Sobieraj (eds.), Lublin 2011.

Kingston S., Surveying the State of EU Environmental Law: Much Bark with Little Bite?, „International and Comparative Law Quarterly” 2013, Vol. 4.

Krämer L., Differentiation in EU Environmental Policy, „European Energy and Environmental Law Review" 2000, No. 5.

Kurcz B., Komentarz do art. 288 Traktatu o funkcjonowaniu Unii Europejskiej [in:] Traktat o funkcjonowaniu Unii Europejskiej. Komentarz, t. III, A. Wróbel (ed.), Warszawa 2012.

Macintosh A., Wilkinson D., Complexity Theory and the Constraints on Environmental Policymaking, „Journal of Environmental Law” 2016, Vol. 28.

Maśnicki J., Metody transpozycji dyrektyw, „Europejski Przegląd Sądowy” 2017, No. 8.

Maśnicki J., Wymuszona implementacja? Postępowania z tytułu uchybienia zobowiązaniom traktatowym $w$ sprawie dyrektyw realizujących polityke energetyczno-klimatyczna [in:] Inteligentna i zrównoważona gospodarka sprzyjajaca włączeniu społecznemu - wyzwania dla systemów prawnych Unii Europejskiej i państw członkowskich, S. Dudzik, B. Iwańska, N. Półtorak (eds.), Warszawa 2017.

Miąsik D., Zasada proporcjonalności [in:] Zasady ustrojowe Unii Europejskiej, J. Barcz (ed.), Warszawa 2010.

Osiejewicz J., Harmonizacja prawa państw członkowskich Unii Europejskiej, Warszawa 2016.

Parker C.F., Karlsson C., The European Union as a Global Climate Leader: Confronting Aspiration with Evidence, „International Environmental Agreements: Politics, Law and Economics" 2017, No. 4.

Przybojewska I., Legal Possibilities of Carbon Capture and Storage in Poland, „Law and Administration in Post-Soviet Europe", Vol. V, G. Górski, A. Garczewska, W. Sławiński, J. Górska-Szymczak (eds.), Torun 2018 (publication pending).

Rietig K., Sustainable Climate Policy Integration in the European Union, „Environmental Policy and Governance" 2013, Vol. 23.

de Sadeleer N., Principle of Subsidiarity and the EU Environmental Policy, „Journal of European Environmental and Planning Law" 2012, No. 1.

Skjærseth J.B., Linking EU Climate and Energy Policies: Policy-Making, Implementation and Reform, „International Environmental Agreements: Politics, Law and Economics" 2016, Vol. 16.

Sommer J., The Organisational and Legal Instruments Available for Harmonising Polish Environmental Law with EC Environmental Law [in:] Reform in CEE-Co- 
untries with Regard to European Enlargement, M. Schmidt et al. (ed.), BerlinHeidelberg 2004.

Sozański J., Ogólne zasady prawa (po traktacie lizbońskim) a wartości Unii Europejskiej - studium prawnoporównawcze, Torun 2012.

Sozański J., Prawo Unii Europejskiej. Analiza krytyczna systemu i doktryny, Toruń 2014.

Stelmachowski M., Handel pozwoleniami na emisję ditlenku węgla jako instrument strategii zrównoważonego rozwoju, Łódź 2006.

Wennerås P., The Enforcement of EC Environmental Law, Oxford 2007.

\section{Acts of law}

Treaty on the Functioning of the European Union (consolidated version), OJ C 83 of 30.03.2010, p. 47-200.

Directive 2003/87/EC of the European Parliament and of the Council of 13 October 2003 establishing a scheme for greenhouse gas emission allowance trading within the Community and amending Council Directive 96/61/EC, OJ L 275 of 25.10 .2003 , p. 32-46, as amended.

Directive 2009/28/WE of the European Parliament and of the Council of of 23 April 2009 on the promotion of the use of energy from renewable sources and amending and subsequently repealing Directives 2001/77/EC and 2003/30/EC, OJ L 140, 05.06.2009, p. 16-62, as amended.

Directive 2009/31/EC of the European Parliament and of the Council of 23 April 2009 on the geological storage of carbon dioxide and amending Council Directive 85/337/EEC, European Parliament and Council Directives 2000/60/EC, 2001/80/EC, 2004/35/EC, 2006/12/EC, 2008/1/EC and Regulation (EC) No 1013/2006, OJ L 140 of 5.06.2009, p. 114-135, as amended.

Act of 20 February 2015 on renewable energy sources, OJ 2015, item 478, as amended.

Act of 17 July 2009 on the system of management of emissions of greenhouse gases and other substances, uniform text OJ 2017, item 286, as amended.

Act of 27 September 2013 on amendment of the act - geological and mining law and some other acts, OJ 2013, item 1238.

Act of 12 June 2015 on the system of trading of greenhouse gases emissions quotas, uniform text OJ 2017, item 568, as amended.

Regulation of the Minister of Environment of 3 September 2014 on areas where localization of a complex of underground geological storage of carbon dioxide, OJ 2014, item 1272.

Regulation of the Minister of Environment of 30 October 2015 on detailed requirements concerning exploitation of an underground storage site of carbon dioxide, pumped stream of carbon dioxide and maintenance of monitoring of a complex of underground carbon dioxide storage, OJ 2015, item 1840.

\section{Judgments}

Judgment of the European Court of Justice of 25 April 2002 in C-183/00, Maria Victoria González Sánchez against Medicina Asturiana SA.

Abstract

The present article describes different methods of harmonisation applied in directives falling into the domain of the energy and climate policy of the European Union. The 
differences in that regard are not without significance with regard to the content and interpretation of domestic law; to the contrary, such issues deeply influence not only the aforementioned but also the sheer effectiveness of legal acts. The article starts with a short description of the nature and basic types of harmonisation that are generally employed by EU directives. After analysis of the features of harmonisation in general terms as well as of various types of harmonisation, the focus shifts to the more specific issue of harmonisation used within the scope of the EU's environmental policy. Next, a case study is presented using the emissions trading directive and the carbon capture and storage directive in order to draw conclusions with regard to the consequences of the choice of a given type of harmonisation.

Keywords: harmonisation, energy policy, climate policy, emissions trading, renewable energy sources

\section{Metody harmonizacji przewidziane dyrektywami klimatyczno-energetycznymi UE oraz ich wpływ na kształt i wykładnię prawa krajowego}

Streszczenie

W niniejszym artykule opisano różne metody harmonizacji stosowane w dyrektywach unijnych w obszarze polityki energetycznej i klimatycznej UE. Różnice w tym zakresie dotyczą kształtu i wykładni prawa krajowego i głęboko wpływają nie tylko na te elementy, ale także i na zwykłą skuteczność aktów prawnych. Punkt wyjścia rozważań stanowi krótki opis charakteru oraz podstawowych typów harmonizacji ogólnie stosowanych w dyrektywach UE. Po analizie cech harmonizacji w ujęciu ogólnym, jak również różnych rodzajów harmonizacji, autorka skupia się na zagadnieniu harmonizacji stosowanej w zakresie polityki środowiskowej Unii Europejskiej. Następnie przedstawiono analizę przypadku $\mathrm{z}$ wykorzystaniem dyrektywy w sprawie system handlu emisjami oraz dyrektywy w sprawie wychwytywania i składowania dwutlenku węgla w celu wyciągnięcia wniosków co do skutków wyboru danego typu harmonizacji.

Słowa kluczowe: harmonizacja, polityka energetyczna, polityka klimatyczna, handel emisjami, odnawialne źródła energii 